\title{
DECISION SELECTION MODEL OF LANDING BEACH IN AMPHIBIOUS OPERATIONS EXCERCISE WITH FUZZY MCDM
}

\author{
Agus Setiadji ${ }^{1}$, Benny Sukandari ${ }^{2}$, Joni Widjayanto ${ }^{3}$, Rifki Najib ${ }^{4}$ \\ 1, 4 Indonesian Naval Technology College, STTAL, Surabaya, Indonesia \\ 2 Indonesia Naval Staff and Command College, Seskoal Jakarta Indonesia \\ ${ }^{3}$ Indonesia Defense University, Unhan, Jakarta Indonesia
}

\begin{abstract}
To determine the ideal landing beaches in amphibious operations must meet the requirements / criteria that have been determined, because it serves as an important component in the choice of landing beaches. The criteria include the type of beach, gradient beach, the basic material of beach, long beach landings, the type of breaking waves, tide, the kind of obstacles beach, ocean currents, the field behind the beach, the reference point mark landing beaches and access to the exit / entrance beach, In determining the selection of the landing beaches Marine / Navy had not done the calculation / mathematical model and not using a scientific method, such instances it is necessary to make a decision-making model in the case of election of the landing beaches in amphibious operations exercise. This study aims to determine the location of the landing beaches using Fuzzy MCDM. The use of this method is the solution to produce a more objective group decision in the selection of an amphibious landing beach which data are accurate and reliable to help solve problems that are multi-criteria. There are 11 (eleven) criteria and 4 (four) alternatives identified in this study. Of the 11 criteria which have the highest weighting criteria for the alternative chosen in the first rank third alternative, namely PPD 3.
\end{abstract}

Keywords: Amphibious Operations, Fuzzy MCDM, Criteria and Alternatives.

\section{INTRODUCTION}

Indonesia is the largest archipelago in the world with a very wide maritime region with a total coastline of about 81,000 and has more than 17,000 islands and sea area of 5.8 or about $70 \%$ of the total area of Indonesia (Son et al. 2017)it is considered reasonable and necessary in particular to safeguard and maintain the sea space through the development and strengthening of the navy for the defense and security of the sea or the territorial waters of various Threats Challenges Obstacles and Interference (ATHG) and war crimes or Military Operations War (OMP) and crimes other than war or Military Operations Other Than war (MOOTW) (Law on the TNI, 2004).

It mainly beach aspect as the entrance of the enemy or friend is very important as a means / media entrance military forces to invade / landing forces occupied the region alone an enemy or enemy territory in particular. Not possible enemy forces will come suddenly through the land / land while our country is surrounded by sea. In the Indonesian Defense White Paper 2015 contains some of the content on strategic environmental development, the essence of the country's defense, policies, strategies and capacity building of national defense, the defense industry, international cooperation in the field of defense, civil defense, defense posture state, the defense of the country and the last on a budget National Defense. Asia-Pacific region is a strategic area, both in terms of economic, political, and military (Defense White Paper of Indonesia, 2015). In the perspective of the traditional security of this region has opportunities and challenges are very complex, as well as the risk factors that can lead to conflicts between states. 
Navy in carrying out its mission have a unity which is called the Integrated Fleet Weapon System (SSAT) with its components in the form of warships of the Republic of Indonesia (KRI). Aircraft (Pesud), Base and the last of the Marines. The SSAT All components must have the ability, strength and preparedness that are reliable and always primed to support the main tasks of the Navy in maintaining the integrity and sovereignty of the Homeland at sea.

Marine has the principal task of carrying out the landing operations at the beach landing in the territory of the opponent or his own territory controlled by the opponent, in-depth look at the terms of the determination of the landing beaches (Collins, 1998), the parameters and characteristics of the ideal (Brink, 2000) from the beach the landing of the troops landing marines are required to carry out its main task as Operation Amphibious landing forces (TNI's doctrine on amphibious operations, 2013).

The decision process selecting the landing beaches in the exercise amphibious operations has a data source multicriteria the form of quantitative and qualitative data in the form of parameters and preferences of the factors that should be considered by decision makers, these criteria it is important to be calculated, assessed and analyzed, if wrong in calculating and analyzing these criteria then have fatal consequences for the implementation of a landing of troops in amphibious operations. In taking the decision determining or selecting the landing beaches, marines takes precision and accuracy in determining, weighting each criterion in each of the alternatives to be chosen as the best alternative so that it takes a rapid method,

The method for weighting each criterion in each of the alternatives available determined weights to the criteria of assessment criteria from one to the next so comes the criteria of the highest value to the criteria of the lowest weight weighed. Then from the weighting of each criterion was to get the best alternative use alternative criteria assessment of each individual. This has become very complex and contradictory, if there is a good alternative to the criteria of the will but there is a second alternative with better criteria than the criteria on the alternative one.

Very precise picture of the situation on the model of fuzzy concept that has been widely used as a model to build a decision support system, one that is Fuzzy MultiCriteria Decision Making (FMCDM). In some studies revealed that, MCDM is a method which refers to the process of screening, prioritizing, ranking, or choose an alternative set. MCDM is apt to be implemented in the case of multiple criteria with all the alternatives have the weight criteria in nominal terms. But for the problems of the process of determining the election alternate landing beaches in amphibious operations exercise is not at all the alternatives have nominal weighted criteria, for example, ease of use etc. So to overcome this,

Current conditions in the selection of the landing beaches in training and real implementation of amphibious operations done conventionally by the decision of the Commander of Joint Task Amphibians (Pangkogasgabfib), Commander Amphibious Landing and Task Force Commander of air incorporated in the organization Kogasgabfib have accrued parallel (Bujuklak Operation Operation Amphibians , 2013), so much affected by the subjectivity and objectivity of the decisionmakers. Another constraint is not done a model / tools / methods elections to decide / make a choice in making decisions for the decision makers in the case of the selection exercise the landing beaches in the amphibious operations.

\section{Formulation of the problem}

Formulation of the problem can be formulated in the absence of decisionmaking model Multi-Criteria Decision Making (MCDM) in the determination of the exercise alternate landing beaches in amphibious operations. To answer the problem formulation found research constraints. These constraints are not done a model / method of election to decide / make a choice in making decisions for the decision makers 
in the case of the selection exercise the landing beaches in the amphibious operations. The research question in this research is:

a. How to get a decisionmaking model with the election of the landing beaches in amphibious operations exercise with the approach of using methods fuzzy MCDM

b. How to establish the best alternative based on the model defined criteria for obtaining the landing beaches.

\section{MATERIAL AND METHOD}

\section{Theory concepts fuzzy}

The concept of fuzzy theory initiated by Lotfi A. Zadeh in 1965 with her seminar paper "Fuzzy Sets" (Zadeh, 1965). Prior to working with fuzzy theory, Zadeh using control theory. He developed the concept of "state", which is the basic form of the theory of fuzzy control theory modern.Dengan show that all theories can be used as the basic concept of fuzzy or continues membership function. Broadly speaking fuzzy theory can be classified into five main areas, namely:

a. fuzzy Mathematics, Where classical mathematical concept was expanded by changing the classic set with fuzzy sets;

b. Fuzzy Logic and Artificial Intelligence, Which was estimated to be introduced classical logic and expert systems are developed based on fuzzy information and estimates of thought;

c. fuzzy System, Which includes fuzzy control and fuzzy approach to signal processing and communication;

d. Uncertainty and Information, Where the difference of the uncertainty analysis;

e. Fuzzy Decision Making, Where the consideration for the optimization problem.

\section{Membership function}

Membership function (MF) is a curve that shows the mapping of points of input data into membership values (often called the degree of membership) which has the interval between 0 and 1 . One of the ways that can be used to obtain the membership value is through function approach. There are several functions that can be used:

\section{a. Linear Represeniasi}

In the linear representation, mapping input to the degree of membership is described as a straight line. This form is the simplest and be a good choice to approach a concept that less jelas.Ada 2 fuzzy set of linear state, first is the increase in the set began on domain value that has a degree of membership of zero [0] to move to the right toward the domain value that has the higher degree of membership.

Membership functions:

$\mu[x]= \begin{cases}0 ; & x \leq a \\ (x-a) /(b-a) ; & a \leq x \leq b \\ 1 ; & x \geq b\end{cases}$

Second, is the opposite of the first. The straight line starting from the value of the domain with the highest degree of membership on the left side, then move down to the value of a domain that has a lower membership.

Membership functions:

$\mu[x]= \begin{cases}(b-x) /(b-a) ; & a \leq x \leq b \\ 0 ; & x \geq b\end{cases}$

\section{b. Curve representation Triangle}

Curves triangle is basically a combination of the two lines (linear).

Membership functions:

$\mu[x]=$

$\begin{cases}0 ; & x \leq a \text { atau } x \geq c \\ (x-a) /(b-a) ; & a \leq x \leq b \\ (c-x) /(c-b) ; & b \leq x \leq c\end{cases}$

c. Curve representation Trapezoid 
Trapezoidal curve is basically like a triangular shape, just that there is a point which has a membership value 1 .

Membership functions:

$$
\mu[x]= \begin{cases}0 ; & \mathrm{x} \leq \mathrm{a} \text { or } \mathrm{x} \geq \mathrm{d} \\ (\mathrm{Xa}) /(\mathrm{ba}) ; & \mathrm{a} \leq \mathrm{x} \leq \mathrm{b} \\ 1 ; & \mathrm{b} \leq \mathrm{x} \leq \mathrm{c} \\ (\mathrm{Dx}) /(\mathrm{dc}) ; & \mathrm{c} \leq \mathrm{x} \leq \mathrm{d}\end{cases}
$$

\section{Triangular Fuzzy Number (TFN)}

In TFN, every single value (crisp) has a membership function of three values each represent a lower value, the value of the middle and upper grades.

$\mathrm{A}=(\mathrm{a} 1, \mathrm{a} 2, \mathrm{a} 3)$

TFN membership functions for the image above is as follows:

$$
\begin{aligned}
\mu[x]=\quad & 0 \quad \text { for } \mathrm{x}<\mathrm{a}_{1} \\
& =\frac{x-a_{1}}{a_{2}-a_{1}} \text { for } \mathrm{a}_{1}<\mathrm{X}<\mathrm{a} 2 \\
& =\frac{a_{3}-x}{a_{3}-a_{2}} \text { for } \mathrm{a}_{2}<\mathrm{X}<\mathrm{a} 3
\end{aligned}
$$

\section{Defuzzification Value}

Defuzzification is a process of conversion and fuzzy quantity into a fixed quantity, where output and process fuzzy logic can be combined from two or more fuzzy membership functions are defined in accordance with the rules talks. Input and defuzzy process is a fuzzy set obtained from the composition of the fuzzy rules, while the resulting output is a fuzzy set of numbers in the domain. There are several defuzzification methods commonly used are as follows:

a. Centroid method (Center Of Gravity / COG)

In this method, the crisp solution is obtained by taking the center point (z) a fuzzy area.

b. Bisektor Method In this method, the crisp solution is obtained by taking the value of the fuzzy domain that has a membership value of half of the total value of membership in the fuzzy area.

c. Mean of Maximum Method (MOM)

In this method, the crisp solution is obtained by taking the average value of a domain that has a maximum membership value.

d. Largest of Maximum Method (LUM)

In this method, the crisp solution is obtained by taking the largest value of a domain that has a maximum membership value.

e. Smallest of Maximun method (SOM)

In this method, the crisp solution is obtained by taking the smallest value of a domain that has a maximum membership value.

\section{Variable Linguistics}

Linguistic variable is a variable that has a description in the form of fuzzy numbers and more generally a word represented by a fuzzy set. For example, descriptions of the linguistic variables for the temperature can be LOW, MEDIUM and HIGH where these descriptions are expressed as fuzzy (fuzzy value). (Tsoukalas, 1997) .As well as the algebraic variables using numbers as its value while the linguistic variables using words or sentences as values that form a set called the set of "terms" of each value of "term" is a fuzzy variables defined by base variable. While the base variable defines the universe of discourse for all fuzzy variables in the set of "terms" (Jantzen, 1998).

\section{Multiple Criteria Decision Making (MCDM)} Multi-Criteria Decision Making (MCDM)is a decision making method which consists of theories, processes, and analytical methods for making decisions that involve uncertainty, dynamics, and aspects of multi-criteria decision. Multi-Criteria Decision Making (MCDM) is a term used in solving the problems which the MCDM approach is expected to get the best alternative. 
Amphibious Operations military doctrine

Books Doctrine of Army Operations

Amphibians (TNI's doctrine of Operations Amphibians, 2013) and Handbook Implementation Implementation of Operations Amphibious-PUM-5101 (Bujuklakgar Opsfib TNI, 2013) passed by the Chief of Naval Staff with KEP / 1809 / XII / 2013 dated 31 December 2013 in chapter 2 points execution of amphibious operations explained that, amphibious operations are carried out integrating operation of various types of power of the Navy who joined the Armada Integrated Weapon System (SSAT), which is the ship, pesud,Amphibious Landing (Marines) and base (supporting means) is integrated with the assisted and reinforced by elements of force others to an attack against the shore enemies and / or potentially overrun and can also be implemented in a joint operation that is universal if it includes elements Navy and other forces with a balanced force.

Amphibians are marine operations in the sense that the Navy played a leading role, as reflected in the way of implementation of the operation.

\section{Research Methodology}

\section{Data processing}

Having obtained the data from the questionnaire, the next step is to recapitulate the results of a questionnaire and carry out data processing. The processing of data using fuzzy MCDM algoritma.For more details, sequence data processing algorithms using fuzzy MCDM above is as follows (Liang \& Wang, 1994):

a. Weighting results to diagram qualitative criteria for the assessment of Mendapatkan weight value aggregates.

b. The rating results to diagram or preference votes for each alternative is based on existing qualitative criteria.

c. Determining the value of the middle of fuzzy numbers, by adding the value that appears on every level of scale linguistic and then dividing the sum by the number of criteria that value into the level of the linguistic assessment. The mathematical notation is as follows:

$a_{t}=\frac{\sum_{i=1}^{k} \sum_{j} T_{i j}}{\sum_{i=1}^{k} n_{i j}}$

$a_{t} \quad=$ the median value for the fuzzy numbers level

$\mathrm{T}=$ assessment level is very low, low, medium, high and very high.

$\mathrm{n}=$ the amount of scale linguistic scale factor $T$ for an alternative to the $1 \mathrm{st}$ of the i-th factor

$\mathrm{TIJ}=$ The numerical value of the scale linguistic $T$ for an alternative to the 1 st of factor $\mathrm{j}$.

d. Determining the value of the lower limit and upper limit value numbers fuzzy, Where the lower limit value $(\mathrm{ct}=\mathrm{b}(\mathrm{i}-1))$ equal to the level below the median value, while the upper limit value $(b t=b$ ( $i$ -1)) is equal to the central value of the upper level.

e. Determining the aggregate weighting of each qualitative criteria, as used in this study form the linguistic assessment that had a definition of numbers fuzzy triangular, Then the process of aggregation is done is by finding the aggregate value of the respective lower limit value (c), the mean (a) and the upper limit value (b), which can be modeled as follows:

$c_{t}=\frac{\sum_{j=1}^{n} c_{t j}}{n} \quad a_{t}=\frac{\sum_{j=1}^{n} a_{t j}}{n} \quad b_{t}=\frac{\sum_{j=1}^{n} b_{t j}}{n}$

Where:

$\mathrm{CTJ}=$ the limit value $\mathrm{BWH}$ qualitative criteria all the decision-maker $\mathrm{t} j$

ATJ $=$ value to the qualitative criteria middle$t$ by decision makers to $\mathrm{j}$

BTJ = the upper limit value to the qualitative criteria-t by decision makers to $\mathrm{j}$ 
$\mathrm{n}=$ number of assessors (decision maker)

Aggregate value is $\mathrm{N}=\left(\mathrm{c}_{\mathrm{j}}, \mathrm{a}_{\mathrm{j}}, b_{\mathrm{j}}\right.$

Where:

$\mathrm{Nt}$. = Value weighted aggregation of qualitative criteria to $t$

f. Calculating the value of the preferences of each alternative based on qualitative criteria. In the calculation of the aggregate weight of each-masing alternatives for each criterion may look fuzzy aggregate value to the model as follows:

$q_{t}=\frac{\sum_{j=1}^{n} q_{t j}}{n} \quad o_{t}=\frac{\sum_{j=1}^{n} o_{t j}}{n} \quad p_{t}=\frac{\sum_{j=1}^{n} p_{t j}}{n}$

qitj = lower limit value alternative to qualitative criteria all kep $t$ by the makers of all j.

oitj = Value alternative to criteria kualitatif.ke middle-t by decision makers to j.

oitj = Upper limit value alternative to qualitative criteria all kep t by maker $\mathrm{j}$.

$\mathrm{n}=$ Number of assessors (decision maker).

Is the aggregate value of $M_{i t j}=($ Qit, oit, pit)

Where :

$\mathrm{M}_{i t j} \quad=$ Value aggregation weights for the $\mathrm{i}$-th alternative to the qualitative criteria to $t$.

g. Calculating the value of the index fuzzyof the results of the assessment of each alternative to qualitative criteria, denoted $\mathrm{Gi}$. Mit value obtained beforehand and $\mathrm{Nt}$, to get a fuzzy match index value for each $\mathrm{Gi}$ subjective criteria. Here $\mathrm{Gi}$ is not a triangular fuzzy numbers, but rather fuzzy numbers:

$\mathrm{G}_{i}=(Y i, Q i, Z i, H / 1, T / 1, H I 2, U i 1)$

$$
i=1,2 \text {, }
$$

The index value fuzzy was obtained by operating each element of triangular fuzzy numbers from the numbers 2 and 4 with the following notations:

$$
T_{i 1}=\frac{\sum_{t=1}^{k}\left(o_{i t-} q_{i t}\right)\left(a_{t-} c_{t}\right)}{k}
$$

$$
\begin{aligned}
T_{i 2} & =\frac{\sum_{t=1}^{k}\left[q_{i t}\left(a_{t-} c_{t}\right)+c_{t}\left(o_{i t-} q_{i t}\right)\right.}{k} \\
U_{i 1} & =\frac{\sum_{t=1}^{k}\left(p_{i t-} o_{i t}\right)\left(b_{t-} a_{t}\right)}{k} \\
U_{i 2} & =\frac{\sum_{t=1}^{k}\left[b_{t}\left(o_{i t-} p_{i t}\right)+p_{t}\left(a_{t-} b_{t}\right)\right.}{k} \\
H_{i 1} & =\frac{T_{i 2}}{2 T_{i 1}} \\
H_{i 2} & =-\frac{U_{i 2}}{2 U_{i 1}} \\
Y_{i} & =\frac{\sum_{t=1}^{k} q_{i t} c_{t}}{k} \\
Q_{i} & =\frac{\sum_{t=1}^{k} o_{i t} a_{t}}{k} \\
Z_{i} & =\frac{\sum_{t=1}^{k} p_{i t} b_{t}}{k}
\end{aligned}
$$

h. Calculating the value of the utility of each alternative for qualitative criteria.

$$
\begin{aligned}
& U_{t}\left(G_{t}\right)=\frac{1}{2}\left[H_{i 2}-\left(H_{i 2}{ }^{2}+\frac{X_{R}-Z_{i}}{U_{i 1}}\right)^{\frac{1}{2}}+1+H_{i 1}\right. \\
& \left.-\left(H_{i 1}^{2}+\frac{X_{L}-Y_{i}}{T_{i 1}}\right)^{\frac{1}{2}}\right] \\
& X_{R}=\frac{1}{2}\left\{2 x_{1}+2 H_{i 2}\left(x_{2}-x_{1}\right)+\frac{\left(x_{2}-x_{1}\right)^{2}}{U_{i 1}}\right. \\
& -\left(x_{2}\right. \\
& \left.-x_{1}\right)\left[\left\langle2 H_{i 2}+\frac{\left(x_{2}-x_{1}\right)^{2}}{U_{i 1}}\right.\right. \\
& \left.\left.\left.+4 \frac{x_{1}-z_{1}}{U_{i 1}}\right\rangle\right]^{\frac{1}{2}}\right\} \\
& X_{L}=\frac{1}{2}\left\{2 x_{2}+2 H_{i 1}\left(x_{2}-x_{1}\right)+\frac{\left(x_{2}-x_{1}\right)^{2}}{T_{i 1}}\right. \\
& \left.-\left(x_{2}-x_{1}\right)\left[\left\langle 2 H_{i 2}+\frac{\left(x_{2}-x_{1}\right)^{2}}{T_{i 1}}+4 \frac{x_{1}-z_{1}}{T_{i 1}}\right\rangle\right]^{\frac{1}{2}}\right\}
\end{aligned}
$$

The first stage is done is to find criteria and preferences defuzzification value alternative to 
the criteria, which the defuzzification method used is the centroid method. The formula of defuzzification criteria are as follows:

Defuzzifikasi $N_{i t}$

$$
=\frac{\left[\left[\int_{c_{t}}^{a_{t}} \frac{\left(x-c_{t}\right)}{\left(a_{t}-c_{t}\right)} x d x+\int_{a_{t}}^{b_{t}} \frac{\left(x-b_{t}\right)}{\left(a_{t}-b_{t}\right)} x d x\right]\right]}{\left[\left[\int_{c_{t}}^{a_{t}} \frac{\left(x-c_{t}\right)}{\left(a_{t}-c_{t}\right)} d x+\int_{a_{t}}^{b_{t}} \frac{\left(x-b_{t}\right)}{\left(a_{t}-b_{t}\right)} d x\right]\right]}
$$

Where: $\quad t=1,2,3$ criteria

$\mathrm{n}$

While the formula for determining the value of the preference defuzzification alternative to qualitative criteria are as follows:

Defuzzifikasi $M_{i t}$

$$
=\frac{\left[\left[\int_{q_{i t}}^{o_{i t}} \frac{\left(x-q_{i t}\right)}{\left(o_{i t}-q_{i t}\right)} x d x+\int_{o_{i t}}^{p_{i t}} \frac{\left(x-p_{i t}\right)}{\left(a_{t}-p_{i t}\right)} x d x\right]\right]}{\left[\left[\int_{q_{i t} o_{i t}} \frac{\left(x-q_{i t}\right)}{\left(o_{i t}-q_{i t}\right)} d x+\int_{o_{i t}}^{p_{i t}} \frac{\left(x-p_{i t}\right)}{\left(a_{t}-p_{i t}\right)} d x\right]\right]}
$$

Where :

$\mathrm{i}=1,2,3$ alternative, ,.............. $\mathrm{m}$;

$\mathrm{t}=1,2,3$ criteria $n$

i. Calculating the value of the ranking of each alternative based on qualitative criteria by using the following formula:

$$
S T_{i}=\frac{U_{T}\left(G_{i}\right)}{\sum_{i=1}^{m} U_{T}\left(G_{i}\right)}
$$

Where :

$\mathrm{STi}=$ Value of the $\mathrm{i}$-th rank alternatives based on qualitative criteria.

j. Calculating the value of the ranking of each alternative based on quantitative criteria with menNOTICE formula as follows:

$$
O T_{i}=\frac{\sum_{j=1}^{p}\left[T_{i j} l\left(\sum_{i=1}^{m} T_{i j}\right)\right]}{p}
$$

Where :

TIJ = Value (score) of the $\mathrm{i}$-th alternative to quantitative criteria $\mathrm{j}$

$\mathrm{M} \quad=$ Number of alternatives

$\mathrm{p} \quad=$ number of quantitative criteria
OTI = Value of the i-th rank alternatives based on criteria quantitative

k. Calculating the total rank value (end) of each alternative to the criteria of qualitative and quantitative criteria with using the following formula:

$F T_{i}=\frac{S T_{i}+O T_{i}}{\sum V k}, 0 \leq \mathrm{x} \leq 1$

Where:

$\mathrm{STi}=$ Value of the $\mathrm{i}$-th rank alternatives based on qualitative criteria.

OTI = Value of the i-th rank alternatives based on criteria quantitative $\Sigma \mathrm{Vk}=$ Number of variables

$\mathrm{FTI} \quad=$ Value of total rankings for alt $\mathrm{i}$-th

I. Choose the best alternative based on the value of the highest rank.

\section{RESULT AND DISCUSSION}

Preliminary

Input data used in the calculation of this manual is to use a questionnaire. Where this questionnaire given to the authorities in the Navy and the experts / expert in the field of weaponry. The data obtained from the processing of this questionnaire is used to determine the weight of each criterion and the weight of each alternative based on qualitative criteria. In the data processing fuzzy method is used to quantify qualitative data (data that is not certain).

Data Alternatives.From the data acquisition results about the characteristics of each alternative beach that will be selected as the location of amphibious landing beach obtained data. There are four alternatives to be considered in the selection process with data summarized.

\section{Determination}

Amphibious Operations military doctrine (TNI Kep.Panglima No.KEP / 264 / IV / 2013) and the doctrines of the Army / Navy derivatives on amphibious operations outlined some criteria for the beach landing beaches in amphibious operations as shown 
in Table 3.1 Criteria Landing Beach the following :

Table 3.1 Criteria Landing Beach

\begin{tabular}{|c|c|c|c|}
\hline NO & $\begin{array}{l}\text { FACTORS } \\
\text { CONSIDERED }\end{array}$ & $\begin{array}{l}\text { EFFECT OF } \\
\text { OPERATIONS } \\
\text { Amphibians }\end{array}$ & $\begin{array}{l}\text { PARAMETER } \\
\text { S OF THE } \\
\text { IDEAL }\end{array}$ \\
\hline 1 & $\begin{array}{l}\text { Beach type: } \\
\text { a. Straight beach } \\
\text { b. Convex beach } \\
\text { c. Concave beach }\end{array}$ & $\begin{array}{l}\text { a.Pengaruh } \\
\text { against currents } \\
\text { and waves } \\
\text { b. Influence on } \\
\text { the direction of } \\
\text { the shot opponent } \\
\text { coastal defenses }\end{array}$ & straight beach \\
\hline 2 & Long Landing Beach & $\begin{array}{lr}\begin{array}{l}\text { Affect } \\
\text { movement }\end{array} & \text { the } \\
\text { maneuver } & \text { Ship to } \\
\text { Coast } & \text { (GKK) } \\
\text { across } & \text { the } \\
\text { surface } & \\
\end{array}$ & $\begin{array}{l}\text { At least } 200 \\
\text { meters to } 1 \\
\text { (one) Battalion } \\
\text { Landing Team } \\
\text { (BTP) }\end{array}$ \\
\hline 3 & $\begin{array}{l}\text { The composition of } \\
\text { the seabed: } \\
\text { a. Sand } \\
\text { b. Sand pebbles } \\
\text { c. Quicksand } \\
\text { d. Gravel }\end{array}$ & $\begin{array}{lr}\text { Affect } & \text { the } \\
\text { movement } & \\
\text { maneuver } & \text { Ship to } \\
\text { Coast } & (\text { GKK) } \\
\text { across } & \text { the } \\
\text { surface } & \end{array}$ & Sand \\
\hline 4 & $\begin{array}{l}\text { Gradients Beach } \\
\text { a. Steep / steep } \\
\text { (gradient> } 1: 15) \\
\text { b. Moderate } \\
\text { moderate } \\
(1: 15>\text { gradient } \geq \\
1: 30) \\
\text { c. Ramps / gentle } \\
(1: 30>\text { gradient } \geq \\
1: 60) \text { } \\
\text { d. Almost flat / mild } \\
(1: 60>\text { gradient } \geq 1: \\
120) \text { : } \\
\text { e. Flat / flat } \\
\text { (Gradient> 1: 120) }\end{array}$ & $\begin{array}{l}\text { a. Affect the } \\
\text { determination of } \\
\text { the type of boat / } \\
\text { lifeboat landing } \\
\text { b. Affect the types } \\
\text { of breaking waves }\end{array}$ & $\begin{array}{l}\text { The most good } \\
\text { for landing is: } \\
\text { a. Gradients } \\
\text { moderate } \\
\text { moderate } \\
(1: 15>\text { gradient } \\
\geq 1: 30) \\
\text { b. The gradient } \\
\text { of the ramps } \\
\text { gentle } \\
(1: 30>\text { gradient } \\
\geq 1: 60)\end{array}$ \\
\hline 5 & $\begin{array}{l}\text { Breaking wave } \\
\text { a. The types of } \\
\text { breaking waves: } \\
\text { 1) Spilling } \\
\text { 2) Plunging } \\
\text { 3) Collapsing } \\
\text { 4) Surging } \\
\text { b. The highest } \\
\text { significant wave height } \\
\text { and } \\
\text { c. wave period }\end{array}$ & $\begin{array}{l}\text { a. Affect the } \\
\text { lifeboat with } \\
\text { monitoring the } \\
\text { landing and } \\
\text { amphibious } \\
\text { vehicles (ranfib) } \\
\text { b. Determine the } \\
\text { type of the boat } \\
\text { landing and ranfib } \\
\text { to be used for } \\
\text { landing }\end{array}$ & $\begin{array}{l}\text { Selected beach } \\
\text { with spilling } \\
\text { wave type }\end{array}$ \\
\hline 6 & Rear terrain Coast & $\begin{array}{l}\text { a. Matter to } \\
\text { maneuver tanks } \\
\text { and amphibious } \\
\text { vehicles (ranfib) } \\
\text { off the coast. } \\
\text { b. As the area } \\
\text { Stelling / force } \\
\text { protection after } \\
\text { didebarkasi from } \\
\text { the boat landing. }\end{array}$ & $\begin{array}{l}\text { a. Flat with } \\
\text { elevated beach } \\
\text { background. } \\
\text { b. There is a } \\
\text { walk out to the } \\
\text { field behind the } \\
\text { beach. }\end{array}$ \\
\hline 7 & $\begin{array}{l}\text { Tidal } \\
\text { a. Types of ups and } \\
\text { downs: } \\
\text { 1) Single Day } \\
\text { 2) Mixed-leaning daily } \\
\text { ganda } \\
\text { 3) Daily Double } \\
\text { 4) Mixed-leaning daily } \\
\text { Single } \\
\text { b. Differences riding on } \\
\text { a tide of water from } \\
\text { one region to another }\end{array}$ & $\begin{array}{l}\text { a. Kandasnya } \\
\text { prevent lifeboats } \\
\text { when monitoring } \\
\text { the lander. } \\
\text { b. Monitoring the } \\
\text { landing lifeboat } \\
\text { can help as far as } \\
\text { possible }\end{array}$ & $\begin{array}{l}\text { a. Been at the } \\
\text { highest tide } \\
\text { b. Selected } \\
\text { areas to the } \\
\text { type of daily } \\
\text { tidal doubles } \\
\text { and mixed } \\
\text { doubles } \\
\text { leaning daily. }\end{array}$ \\
\hline 8 & $\begin{array}{l}\text { Current } \\
\text { a. The influence of the } \\
\text { tidal currents. } \\
\text { b. Flow influence } \\
\text { breaking waves. }\end{array}$ & $\begin{array}{l}\text { Affect the lifeboat } \\
\text { with monitoring } \\
\text { the landing and } \\
\text { amphibious } \\
\text { vehicles (ranfib) }\end{array}$ & $\begin{array}{l}\text { Longshore } \\
\text { currents with a } \\
\text { speed of }<1 \\
\text { knots }\end{array}$ \\
\hline 9 & Reference point mark & Proper & Can be a sign \\
\hline
\end{tabular}

\begin{tabular}{|c|c|c|c|}
\hline & the landing beaches & $\begin{array}{l}\text { identification of } \\
\text { the landing } \\
\text { beaches } \\
\text { b. As a cross } \\
\text { GKK navigation } \\
\text { guide surface. }\end{array}$ & $\begin{array}{l}\text { of a known } \\
\text { field position, } \\
\text { for example: } \\
\text { Means of } \\
\text { Navigation } \\
\text { Aids (SBN), } \\
\text { buildings, and } \\
\text { others. }\end{array}$ \\
\hline 10 & $\begin{array}{l}\text { Obstacles Beach } \\
\text { a. Natural obstacles } \\
\text { (rocks, burnt, mud, } \\
\text { etc.) } \\
\text { b. Artificial obstacles } \\
\text { (mines, material } \\
\text { obstacles, hindrances } \\
\text { personnel, etc.). }\end{array}$ & $\begin{array}{l}\text { Affect the success } \\
\text { of landing } \\
\text { a. Natural } \\
\text { obstacles can } \\
\text { reduce the speed } \\
\text { of movement of } \\
\text { the landing } \\
\text { vehicle, causing } \\
\text { the vehicle ran } \\
\text { aground, } \\
\text { damaging the } \\
\text { vehicle body, and } \\
\text { others. Artificial } \\
\text { b. obstacles } \\
\text { obstacles (mines } \\
\text { and obstalian needs to } \\
\text { material) } \\
\text { be demolished by } \\
\text { the demolition } \\
\text { before the } \\
\text { implementation of } \\
\text { the cross-surface } \\
\text { GKK }\end{array}$ & \begin{tabular}{l}
\multicolumn{2}{l}{ Selected } \\
natural barrier \\
$\begin{array}{l}\text { beach with } \\
\text { minimal }\end{array}$
\end{tabular} \\
\hline 11 & $\begin{array}{l}\text { Egress } \\
\text { closers) }\end{array}$ & $\begin{array}{l}\text { As the exit } \\
\text { landing vehicles } \\
\text { as well as for the } \\
\text { troops so as to } \\
\text { facilitate entry into } \\
\text { the interior }\end{array}$ & $\begin{array}{l}\text { Beaches have } \\
\text { been pretty } \\
\text { much the way } \\
\text { out so as to } \\
\text { accelerate the } \\
\text { formation into. }\end{array}$ \\
\hline
\end{tabular}

(Source: Kep, TNI Commander NO.KEP / 264 / IV / 2013)

\section{Selection Criteria In Landing Beach}

In this paper, the criteria considered for the selection of appropriate Landing Beach can be divided into two parts, namely quantitative criteria and qualitative criteria. More detail can be illustrated by the figure below:

Quantitative Criteria

Quantitative criteria are criteria that have value for sure, so it can be compared between one option with other options. As for the quantitative criteria are taken into consideration in the selection of Landing Beach are as follows:

a. Long landing Beach

b. Gradient Beach

c. Tide

d. Sea Wave

Qualitative criteria

Qualitative criteria are criteria that do not have the exact value, so as to determine its value should be the quantification of 
qualitative criteria and will obtain the numerical value of qualitative criteria. As for the quantitative criteria are taken into consideration in the selection of Landing Beach are as follows:
a. Type Beach
b. Basic Materials Coast
c. Breaking wave type
d. Rear terrain Coast
e. Reference Point (Signs Coast)
f. Obstacles type Beaches
g. Access Exit / Entrance

\section{Data collection}

Researchers collected data by steps of data collection for completion method of Fuzzy MCDM with interviews and distributing questionnaires to six (6) expert / specialist who has expertise on amphibious operations and hydro-oceanographic owned by the Navy in this case the Marines and Pushidrosal.

The expert in this research isOfficers of the Navy has the academic understanding of Amphibious Operations, Hydrooceanography and have experience in various field assignments office environment with strata education Navy has followed the Navy Command and Staff School or equivalent education Sesko Navy.

\section{Analysis of total aggregate weighting}

In aggregate weighting process for the data of each criteria and alternatives do data processing which aims to find the value of the bottom, middle and top of each criteria and alternatives.

Recap Weight Aggregate Table 4.1 Qualitative criteria

\begin{tabular}{|l|l|l|}
\hline NO & CRITERIA & WEIGHT \\
\hline 1. & Type Beach & 8.2 \\
\hline 2. & Basic Materials Coast & 7,6 \\
\hline 3. & Breaking wave type & 6.1567 \\
\hline 4. & Rear terrain Coast & 7.888 \\
\hline 5. & Reference Point (Signs Coast) & 6.6318 \\
\hline 6. & Obstacles type Beaches & 6.1677 \\
\hline 7. & Access Exit / Entrance & 6.418 \\
\hline
\end{tabular}

Here's a recap of the weight criteria and alternatives produced by fuzzy MCDM indicated by the table (4.1) and (4.2). Recap weights are shown in the table (4.1) only the middle value of each criterion and so also for alternative weight value displayed only on the middle value only.

Table 4.2: Alternative Aggregate Thickness Recap

\begin{tabular}{|c|c|c|c|}
\hline NO & CRITERIA & Mit & Weight \\
\hline \multirow{4}{*}{1.} & \multirow{4}{*}{ Type Beach } & ALT 1 & 7.812 \\
\hline & & ALT 2 & 7.765 \\
\hline & & ALT 3 & 6.95 \\
\hline & & ALT 4 & 8.55 \\
\hline \multirow{4}{*}{2.} & \multirow{4}{*}{$\begin{array}{c}\text { Basic Materials } \\
\text { Coast }\end{array}$} & $\mathrm{ALT} 1$ & 6.623 \\
\hline & & ALT 2 & 6.603 \\
\hline & & ALT 3 & 7.812 \\
\hline & & ALT 4 & 6.94 \\
\hline \multirow{4}{*}{3.} & \multirow{4}{*}{$\begin{array}{c}\text { Breaking Wave } \\
\text { Type }\end{array}$} & ALT 1 & 6.072 \\
\hline & & ALT 2 & 6.333 \\
\hline & & ALT 3 & 9.072 \\
\hline & & ALT 4 & 5.728 \\
\hline \multirow{4}{*}{4.} & \multirow{4}{*}{$\begin{array}{l}\text { Rear terrain } \\
\text { Coast }\end{array}$} & ALT 1 & 6.945 \\
\hline & & ALT 2 & 8.038 \\
\hline & & ALT 3 & 7,535 \\
\hline & & ALT 4 & 7,535 \\
\hline \multirow{4}{*}{5.} & \multirow{4}{*}{$\begin{array}{l}\text { Reference point } \\
\text { (Signs Coast) }\end{array}$} & ALT 1 & 6.962 \\
\hline & & ALT 2 & 7.49 \\
\hline & & ALT 3 & 8.043 \\
\hline & & ALT 4 & 7.132 \\
\hline \multirow{4}{*}{6.} & \multirow{4}{*}{$\begin{array}{c}\text { Obstacles type } \\
\text { Beaches }\end{array}$} & ALT 1 & 6.617 \\
\hline & & ALT 2 & 7.475 \\
\hline & & ALT 3 & 7.78 \\
\hline & & ALT 4 & 6.66 \\
\hline \multirow{4}{*}{7.} & \multirow{4}{*}{$\begin{array}{l}\text { Access Exit / } \\
\text { Entrance }\end{array}$} & ALT 1 & 6.318 \\
\hline & & ALT 2 & 7.46 \\
\hline & & ALT 3 & 8,07 \\
\hline & & ALT 4 & 6,96 \\
\hline
\end{tabular}

Table (4.1) and (4.2) is the result of total aggregate weighting where this weighting function to search for fuzzy index and becomes the data input to do defuzzification.

\section{Fuzzification and defuzzification process analysis}

Defuzzification is the process to obtain a single value of linguistic value. Defuzzification method is best used in fuzzy MCDM is a method of Center of Gravity 
(COG) / method Centroid (Kainz, 2003). By paying attention to these studies the present study using centroid method by taking the Crisp (single value) derived from the middle of the existing fuzzy area that matches the design of the membership function and fuzzy rule base is used.

Table 4.3 Results of defuzzification

\begin{tabular}{|c|c|c|c|c|c|c|}
\hline \multirow{2}{*}{ NO } & \multirow{2}{*}{ CRITERIA } & \multirow{2}{*}{$\begin{array}{l}\text { Cation } \\
\text { Defuzzifi } \\
\text { Weight }\end{array}$} & \multicolumn{4}{|c|}{ Defuzification Alternative } \\
\hline & & & Alt 1 & Alt 2 & Alt3 & Alt 4 \\
\hline 1. & Type Beach & 8212 & 7.672 & 7.678 & 6.707 & 8.392 \\
\hline 2 & $\begin{array}{c}\text { Basic } \\
\text { Materials } \\
\text { Coast } \\
\end{array}$ & 6.013 & 6.436 & 6.596 & 7.672 & 6.414 \\
\hline 3 & $\begin{array}{l}\text { Breaking } \\
\text { Wave Type }\end{array}$ & 7.803 & 5.866 & 6.153 & 8.869 & 5.588 \\
\hline 4. & $\begin{array}{c}\text { Rear terrain } \\
\text { Coast }\end{array}$ & 6.485 & 6.697 & 7.902 & 7.432 & 7.432 \\
\hline 5. & $\begin{array}{c}\text { Retarence } \\
\text { puint (Signs } \\
\text { Cuast) }\end{array}$ & 6.485 & 6.878 & 7.386 & 7.905 & 7.104 \\
\hline 6 & $\begin{array}{c}\text { Obstacles } \\
\text { type } \\
\text { Beaches }\end{array}$ & 5.550 & 6,424 & 7.382 & 7,669 & 6,424 \\
\hline 7. & $\begin{array}{c}\text { Access Exitl } \\
\text { Entrance }\end{array}$ & 6.013 & 6.148 & 7.391 & 7.905 & 6.702 \\
\hline
\end{tabular}

Table 4.4 Value indices forming the evaluation value

\begin{tabular}{|c|c|c|c|c|}
\hline \multirow{2}{*}{ INDEX } & \multicolumn{4}{|c|}{ ALTERNATIVE } \\
\cline { 2 - 5 } & $\mathbf{1}$ & $\mathbf{2}$ & $\mathbf{3}$ & $\mathbf{4}$ \\
\hline Yi & 20.81 & 22.37 & 25.95 & 21.71 \\
\hline $\mathbf{Q i}$ & 47,87 & 49.76 & 54.86 & 48.99 \\
\hline $\mathbf{Z i}$ & 74.13 & 76.16 & 80.93 & 74.14 \\
\hline HI1 & 1,827 & 2,167 & 2.458 & 1,978 \\
\hline Ti1 & 6.014 & 5.318 & 5.106 & 5.681 \\
\hline Hi2 & 5.208 & 5,433 & 5.898 & 5.63 \\
\hline Ui1 & 2,68 & 2,595 & 2.286 & 2.375 \\
\hline Ti2 & 21.98 & 23,05 & 25.1 & 22.47 \\
\hline Ui2 & -27.9 & -28.2 & -27 & -26.74 \\
\hline
\end{tabular}

After forming an index known evaluation values in the table (4.4), the search process is then performed fuzzy membership function value $(F G(x))$ and the fuzzy index Gi which would then be processed into a utility value that can be known which is the best alternative. Here the value of $\mathrm{FGI}(\mathrm{x})$ and $\mathrm{Gi}$ shown in the table (4.5).

Table 4.5 Value FGI (x) and $\mathrm{Gi}$

\begin{tabular}{|c|c|c|c|c|}
\hline SCORE & Alt 1 & Alt 2 & Alt 3 & Alt 4 \\
\hline $\mathrm{Gi}$ & 45,100 & 47.172 & 51.961 & 45.976 \\
\hline $\mathrm{FGl}(\mathrm{x})$ & 0.834 & 0.895 & 0.988 & 0.910 \\
\hline
\end{tabular}

Having in mind the fuzzy index value, then the next step is a search utility value for each alternative based on qualitative criteria. By use of the results of the utility value can be seen in the table below:

Table 4.6 Value Sti (Qualitative) any Alternative

\begin{tabular}{|c|c|c|c|c|}
\hline SCORE & Alt 1 & Alt 2 & Alt 3 & Alt 4 \\
\hline Sti & 0.230 & 0.247 & 0.272 & 0.251 \\
\hline
\end{tabular}

Likewise for quantitative criteria also searched his utility value by using the results of the utility value equation for quantitative criteria can be seen in the table below:

Table 4.7 Value OTI (Quantitative) any Alternative

\begin{tabular}{|c|c|c|c|c|}
\hline SCORE & Alt 1 & Alt 2 & Alt 3 & Alt 4 \\
\hline OTI & 0.234 & 0.247 & 0.281 & 0.237 \\
\hline
\end{tabular}

From (table 4.7) above can be seen the utility value of each alternative. Of 4 of these alternatives can be seen that alternative 3 has the highest utility value 0.281 followed by a second alternative of 0 .247 , Alternative 4 alternative last 0.237 and 1 is 0.234 .

Finally, to get the total ranking score for each alternative both qualitative and quantitative criteria using the equation above, the end result is shown in table (4.8) the following: 
Table 4.8 The total value of each alternative

\begin{tabular}{|c|c|c|c|c|}
\hline VALUE & Alt 1 & Alt 2 & Alt 3 & Alt 4 \\
\hline FTi & 0,232 & 0,247 & 0,277 & 0,244 \\
\hline RANGK & IV & II & I & III \\
\hline
\end{tabular}

\section{CONCLUSIONS}

\section{Conclusion}

Decision-making within an organization within the available time is sometimes quite short is the result of a process of communication, participation and preferences directly and continuously from every member of the organization. Using appropriate methods, good and true in a decision-making is the right decision and the best to deliver the best outcome. Decisionmaking model by using Fuzzy MCDM is a way to connect a selection of each alternative preferences and criteria into a mathematical language to produce a definite result calculations and measured values.

Based on the results of research and data processing on election priority the landing beaches by using fuzzy MCDM it can be concluded as follows:

a. Multicriteria decision making model already had been applied in the selection of the landing beaches discretion multiple criteria decision making.

b. In conducting the landing beaches selection criteria required for consideration can be classified into two groups: qualitative criteria and quantitative criteria.

c. The decision making process in election the landing beaches This is not done by one person alone, but involves a lot of people, so that every decision maker will give a different assessment of the criteria as well as alternative choices.

d. Fuzzy algorithm can be applied in the selection the landing beaches, Because in this fuzzy method can quantify qualitative criteria (vague). e. Based on calculations by using a computer program then obtained fuzzy MCDM the landing beaches elect is PPD 3 with the total value of the highest rank, namely 0.277 .

\section{FUTURE WORK}

a. For the practitioner or the Marines and Navy in particular for the leadership of the Navy that this research can be used for decision support and as planning in determining the location of the landing beaches in amphibious operations exercise.

b. For academics/ researchers in future research in order to be made similar research / advanced to do with the development / additional criteria, alternatives and opinion of the experts in the questionnaire in order to give a final decision on ranking results more accurate. As can combine with other MCDM method using several methods simultaneously as the comparison results obtained to then expect to achieve the advantages and disadvantages of each method used in the interests of science and military science future Navy.

\section{ACKNOWLEDGEMENT}

The authors greatly acknowledge the support from STTAL Surabaya Indonesia, Unhan Jakarta, and Seskoal Jakarta for providing the necessary resources to carry out this research work. The authors are also grateful to the anonymous reviewers and journal editorial board for their many insightful comments, which have significantly improved this article.

\section{REFERENCES}

Alper, D. \& Basdar, C. (2017). A Comparision of TOPSIS and elctre methods: an application on the 
factoring industry. Business and Economics Reasearch Journal, vol.8, no.3.

Brink, KH (2000). Oceanography and Mine Warefare, Ocean Studies Board Commission on Geoscience, Environment and Resource. Washington, DC, USA: National Research Council.

Ciptomulyono, U. (2010). Multi-Criteria Decision Making Paradigm in the Perspective of Project Development and Environment Industry Yang Berwawaskan. Inauguration speech for Professor Position In MultiCriteria Decision Sciences Division at the Department of Industrial Engineering ITS. Journal of Industrial Engineering ITS Surabaya.

Collins, JM (1998). Military Goegraphy for Professional and Public. Washington, DC, USA: National Defense University Press.

Dubois, D., \& Prade, H. (1979). Operations in a Fuzzy-Valued Logic. Information and Control, 224-240.

Hill, SG, lavecchia, HP, Alvah C. Bittner, J., Zaklad, AL, \& Christ, RE (1992). Workload Comparison of Four Subjective Rating Scales. The Journal of the Human Factors and Ergonomics Society, 429-439.

Hwang, C. d. (1981). Multiple Attribute Decision makig: Methods and Application: A Sate of the Art, Survey Lectures Notes in Economics and Mathematical Systems. Springer Verlag, Berlin Germany.

TNI. (2013). TNI doctrine of amphibious operations. Jakarta: TNI.

Navy Headquarters. (1991). Consideration of Its Underlying Determination
Bujuklap Basic Decision On Amphibious Operations. Jakarta: Indonesian Navy Headquarters.

Navy Headquarters. (2013). Bujuklakgar Opsfib TNI. Jakarta: Indonesian Navy Headquarters.

Navy Headquarters. (2004). TNI Law 34 of 2004 Article 9. Jakarta: TNI.

Navy Headquarters. (2006). Navy's doctrine - Eka Sasana Jaya. JAKARTA: Indonesian Navy.

Navy Headquarters. (2013). Bujuklakgar Opsfib-PUM-5101. Jakarta: Indonesian Navy.

Navy Headquarters. (2013). TNI doctrine of amphibious operations. Jakarta: TNI.

Navy Headquarters. (2013). Self Army / Navy. Jakarta: Indonesian Navy.

Navy Headquarters. (2013). PUM-5-101 Implementation Bujuklak Amphibious Operations. Jakarta: Indonesian Navy.

TNI. (2009). Perpang TNI / 45 / VII / 2009 on technical guidelines Position Appointment and Dismissal In the military structure. Jakarta.

Pushidrosal. (2015). Field Report Survey Tapaktuan South Aceh Pushidrosal 2015. Jakarta: Pushidrosal Navy.

Pushidrosal \& BIG. (2018). National Referral Indonesian territorial data. Jakarta: Pushidrosal Navy.

Sanders, MS, \& McCormick, EJ (1993). Human Factors in Engineering and Design Seventh Edition. New York: McGraw-Hili, Inc.

Stewart, BV (2002). Multiple Criteria Decisioan Analysis: An Integrated Approach. Kluwer Academic Publishers. 
UNCLOS. (1982). United Nations Convention On The Law Of The Sea. New York, USA.

RI Law. (2004). Republic Act No.34 of 2004 on the TNI. Jakarta: Indonesian Government.

Tzeng, G-H.,Liang,J.,Neng,H dan Huei, $R$, (2008). Vendor selection by integrated Fuzzy MCDM techniques with independent and interdependent relationships. Information Science. 178.41664184.

Wang dan Liang, (1994), A hierarchy fuzzy MCDM method for studying electronic marketing strategies in the informations service industry. International Journal Inf Manage, Vol 8,1-22.

Zadeh, Lotfi A, (1974) Fuzzy sets and their applications to cognitive and decision processes. The University of California, Berkeley, California July 1-4, 197 